\title{
SOCIAL IDENTITY EXPRESSIONS IN KEVIN KWAN'S CRAZY RICH ASIANS
}

\author{
${ }^{\mathrm{a}}$ Nailul Ifada, ${ }^{\mathrm{b}}$ Zakiyatul Mufidah \\ ${ }^{\mathrm{a}, \mathrm{b}}$ English Study Program, University of Trunojoyo Madura \\ e-mail: zakiyatul.mufidah@trunojoyo.ac.id
}

\begin{abstract}
The study deals with the expression of social identity in Asians elite community circle found in the novel Crazy Rich Asians by Kevin Kwan. Primary data regarding social identity expressions are noted based on the characters' utterances and author's narration found in the novel. The study is categorized as qualitative research as the data are displayed in the form of words from the novel's original language. The methods of collecting data used by the writer are reading and labeling. The writer acts as the mere observer without other instruments included. Data analysis method includes compiling, disassembling, reassembling, interpreting and concluding based on Robert K. Yin's techniques of analyzing data. The results indicate that there are a number of social identity expressions in Kwan's Crazy Rich Asians. There are two significant ways of expressing social identity of the rich: (1) the patterns of consumption including food, fashion, and personal luxury belongings. (2) social image maintenance through early education, interaction, special occasion and club membership.
\end{abstract}

Keywords: Social Identity, Social Image, Patterns of Consumption, Wealth, Rich Community. 


\section{INTRODUCTION}

Ever since humans were born, they have carried with them something known as identity. Whether they are born as a boy or a girl, white or black, and how they will be recognized by others. Barker (2000) agrees that "To explore identity is to enquire: how do we see ourselves and how others see us?" (p. 165).

Identity, to begin with, is a somehow tricky concept and cannot actually be clearly defined. Even though we may response towards the question of "what is one's identity?" by explaining what one is like, Hall (1996) argued that identity is a concept that operates between reversal and emergence; an idea which cannot be thought in the old simple way. On the other hand, regardless of how complicated identity might seem, it can be articulated and expressed in a particular definitive way. It can as well be formed through several ways and by certain media, adaptive from time to time. "Identity becomes a 'moveable feast': formed and transformed continuously in relation to the ways we are represented or addressed in the cultural systems which surround us" (Hall, Held, \& Thompson, 1996, p. 277).

Another supporting idea is confirmed by Chua (2000) in a section of his book, Consuming Asians: Ideas and Issues, who assured that identity can be formed by examining the individual's objects of consumption and their lifestyle. Mass or excessive consumerism in various sectors of industries is seen as an instrument of one's success and social prestige. As well as their lifestyle on a daily basis.

\section{PATTERNS OF CONSUMPTION}

\section{A. Fashion}

The term fashion according to Davis (1994) differs from its other neighbor terms in a way we relate the kind of clothes with the meaning it conveys. It might include the brands, price, and materials in fashion as a symbol and language to resemble one's social status. Despite all the speculation that has been going around that these luxury brands overprice their products and give an absolute extra credit to the brand itself rather than the actual materials their products are made of, they are still standing at the top of the fashion industry, leading, and even making the trends.

One of the characters in the novel, Astrid Leong was portrayed as a woman of style and elegance. Astrid's style of dressing never failed to impress anyone who happened to lay eyes on her. When she was at a sumptuous ball in Paris, a woman even approached her just to make sure if the dress she was wearing was from its original designer. She responded calmly as noted in the dialog below.

"Wait a minute, is this an original Madame Grès?"

"From her early period."

"But of course. My goodness, Astrid, you've outdone yourself once again.

How on earth did you get your hands on an early Grès?"

(Kwan, 2013, p. 42)

Once a well-known fashion designer has stopped producing a certain type of product, its price will gradually be rising. The rarer a fashion item is, the more expensive it becomes. This only applies to a very limited recognized fashion brands, one of them is Madame Grès. Madame Grès is a fashion brand originated from France. It produces various vintage collections that even fashion scholars have trouble linking 
back to the date in which the particular dress or fashion piece were famous. Not everyone could own this brand's rare pieces even though they have the money it takes.

A Collette Dinnigan skirt could worth up to $\$ 400$ per item, and then there is Tomar Maier blouse for around the same price. The last items these girls are fighting over are Pierre Hardy flats and a pair of stilettos by an Australian designer, Nicholas Kirkwood, which unbelievably cost no less than $\$ 600$ each. With such an unreasonable price, there must be something worth arguing about, whether it is the materials, labor fee, or simply the brand logo. At the end of the day, a company is a company anyway. No matter how good the materials or their labors are, its main goal is to earn money and make profit. Some believe that recognized brands charge for the actual brand itself rather than the products. It is, hence, has gone too far from the functional purpose of a product, but more like a matter of pride that speaks for the wearer's social status.

\section{B. Food}

The quality of dish is one aspect that is able to distinguish the middle and upper class. Corrigan (1997) admitted that an important change that contributed to the civilizing of appetite was the shift from stressing the sheer quantity of food consumed to the more delicate and complex question of the quality of the food.

Along one of the arcades stretched long banquet tables that displayed a wondrous selection of desserts. There were elaborate cakes, soufflés, and sweet puddings there was goreng pisang drizzled with Lyle's Golden Syrup, nyonya kuehs in every color of the rainbow, and tall polished samovars filled with different steaming-hot elixirs. Servers wearing white toques stood behind each table, ready to dish out the delicacies.

(Kwan, 2013, p. 194)

The various choice of dish lay out by the host was incredible. Not only was the quantity, the food was served by personal hired chefs whose concern was on the taste. As confirmed by Corrigan (1997) who believed that the essence of food is not to fulfill one's hunger but rather spoil the tongue with good quality food.

\section{Luxury Goods}

Rachel Chu who had been in a relationship with Nicholas Young for over two years were not sure if she should agree with him on flying to Singapore to attend Nick's best friend, Colin Khoo's wedding. There were a lot of things going on her mind. She was afraid she could not present herself well in front of Nick's family for the first time. Moreover, not once did Nick ever give her a single detail on his family. Once Rachel had finally made up her mind, she was absolutely confused at the airport knowing Nick had bought a first-class ticket to Singapore without telling her.

"You're kidding right?" Rachel said, thinking Nick was a pulling a prank when he steered her onto the plush red carpet of the Singapore Airlines first-class counter at JFK.

(Kwan, 2013, p. 84) 
Rachel's tone of surprise indicates that she might have caught the first hint of what Nick's overseas family would be like, even though she was not quite sure yet. During their time living in New York as immigrants, Nick was much more of a downto-earth guy in spite of always getting dressed nicely. Thus, Rachel did not consider buying a first-class plane ticket okay, to her it was a little too much. On the other side, she did not want all the money Nick had spent on the tickets gone for nothing, she ended up enjoying the benefits anyway. It was once in a lifetime chance for a middleclass woman like her to be able to fly in a VIP seat.

As things got more and more surreal, the author of the novel, Kwan, revealed Edison Cheng's insane amount of private cars that practically represents the lavish life of Asian millionaires. Eddie is Nick's uncle who likes bragging about his money and luxury possessions. He perceived sports cars as the one symbol to make him recognizable and stand out among other typical middle-class citizens. The basic and main purpose of vehicles which is actually to bring someone from one place to another, has shifted and become a show-off time instead.

In the parking garage of their building, they owned five parking spots (valued at two hundred and fifty thousand each) where their fleet consisted of a Bentley Continental GT (Eddie's weekday car), an Aston Martin Vanquish (Eddie's weekend car), a Volvo S40 (Fiona's car), a Mercedes S550 (the family car), and a Porsche Cayenne (the family sport-utility vehicle).

(Kwan, 2013, p. 80)

The passage shows that Eddie found it satisfying to be seen owning several expensive sports car and driving in one. It improves his self-esteem and feeds his hunger of admiration. Only a very wealthy person could afford several cars for different occasions. He had two specifically designed cars to fit more people since he has three children, one for his wife, and two more cars for himself for both weekdays and weekends. Shockingly, compared to his other friends who seem to own more and more private jets, he considered all these cars a bit of an embarrassment. He put the blame on his own parents who he thought were too stingy. If only they had spoiled him a little more, he would have gotten his own yacht and whatever else he desired.

\section{SOCIAL IMAGE MAINTENANCE}

\section{A. Interaction}

Another interesting way to portray the social life of elite milieu is by analyzing how they mingle. According to Stuart Hall, social identity is formed and carried socially through and in the interaction with others. As well as other social beings, Nick's family members naturally tend to connect with people in their surroundings, although, unlike others, the standard of whom they can mingle with might be considerably limited.

"Colin, we can't have just anyone over, you know. We must know who the family is first. This isn't like California-you have to be so very careful about what sort of people you associate with here."

(Kwan, 2013, p. 253) 
The quotation above is taken from the dialogue between Colin Khoo (Nick's best friend) and his grandfather when Colin was caught bringing his unknown friend home. Just like Nick's family, Colin's is also well-known for their success story and is one of the elite in Singapore. His grandfather got really mad when he saw an unfamiliar face in his house and told Colin not to bring his friend home ever again. However, he noticed that when he invited Nick home, his grandfather treated Nick tremendously different from his other friends. Since then, he realized it was because of the 'Young' entitled on Nick's name, a family Surname everyone respected in Singapore. Colin had eventually dealt with the fact that he could only be really close with a certain category of people based on his family's approval.

Not only do the parents get to decide whom their children can be friends with, they also have regular fellowship activities, attend friend gatherings, and have private family dinners at some fancy restaurant. This will evoke the feeling of mutuality for being in the same circle of rich community.

\section{B. Education}

Rich parents have their own distinctive way of raising their children. However strict it may seem for most common people, they want to set the right path so that these children could follow their success, maintain the good name of the family, and end up living a luxury life everyone dreams of. As the author narrated in the quotation below, the girls of Singaporean billionaires were sent to various elite schools to get quality education, both materially and morally.

For the small of girls growing up within Singapore most elite milieu, life followed a prescribed order: beginning at age six, you were enrolled at Methodist Girls' School (MGS) Singapore Chinese Girl School (SCGS), or the Convent of the Holy Infant Jesus (CHIJ). After-school hours were consumed by a team of tutors preparing you for the avalanche of weekly exams (usually in classical Mandarin literature, multivariable calculus, and molecular biology), followed on the weekends by piano, violin, ballet, or reading, and some sort of Christian Youth Fellowship activity.

(Kwan, 2013, p. 71)

The quotation above indicates how strict the rules of education are among Singaporean rich daughters. It does not seem exaggerated knowing the fact that almost everyone agrees on the importance of education for a promising life. Poor parents would even provide education for their children as much as they could afford, wishing that their children would end up with a better life. Meanwhile, the group of Singaporean rich people has different goals in sending their children to private elite schools. Some of them do it for reason of quality, but not infrequently, some tend to force their children to get into elite schools with strict qualifications merely for the sake of prestige. Apparently these two things are inseparable and in some way related to one another. 


\section{Club Memberships}

Having a social status that is considered prestigious for most people makes Nick's family have exclusive access to various luxury facilities, for example Eddie. Eddie joined in many sports and other fancy clubs. Clearly, this club membership card can only be owned by people with financial ability that's above average.

Eddie was a member of the Chinese Athletic Association, the Hong Kong Golf Club, the China Club, the Hong Kong Club, the Cricket Club, the Dynasty Club, the American Club, the Jockey Club, the Royal Hong Kong Yacht, and too many private dining clubs to recount.

(Kwan, 2013, p. 80)

No one in this world could have been vainer than Eddie. He had access to every possible fancy restaurant, sports, and other elite facilities by only showing his member cards. The membership of these clubs is so exclusive that only those with big money could afford and join.

\section{Special Occasions}

Getting a little bit of a grip of what Nick's Family is like, Rachel was then invited to a party before Araminta and Colin's wedding. It was held by Shang Su Yi, Nick's Grandmother, who yet remained one of the most respected women in Singapore and among other Chinese elite. She really took a special interest in tan hua flowers that she even willingly invited other rich families to witness her flowers bloom.

\footnotetext{
"I hope it's okay . . . but it's not just the family. My grandmother decided to have a small party, all arranged at the last minute, apparently, because her tan hua flowers are going to bloom tonight."

"She's throwing a party because her flowers are in bloom?" Rachel asked, not quite following.
}

(Kwan, 2013, p. 171)

In the novel, $\mathrm{Su} \mathrm{Yi}$ was portrayed as one of the most respectable women for having been married to Sir James Young, who inherited his huge family fortune. Whenever Su Yi held a private party, like tan hua's party, everyone felt that it was mandatory to accept her invitation. In fact, the invitation itself was an honor for anyone who received it, because they knew Su Yi wouldn't want a stranger from a middleclass citizen to be at her luxury party.

Not only in private parties, rich people would go all out when it comes to a once in a lifetime event, like a wedding reception. This noticeable sign of wealth is found in Colin and Araminta's wedding plans, both of whom are close friends with Nick. Looking at the details of each event in this wedding, it is not too much if the marriage of these two lovebirds is predicted to be the highlight of the year in various magazines. The reason is not merely because there would be guests from among the elite, but rather because the details of the wedding itself are truly magnificent. 
Boden (2003) believed that weddings have always been structured around forms of 'consumption' of a sort, based around the symbolic and communicative qualities of material objects. Yet, today's weddings offer a more dynamic opportunity for both grooms and brides to have an event that is relevant and appropriate to them. They can actively shape and construct the event based on their personal and social situation depending on how much they could afford.

\section{CONCLUSION}

The first social identity expression is reflected in the consumption pattern which is further divided into three subsections such as food, fashion, and luxury ownership. Wealthy people in Crazy Rich Asians make fashion a way to represent their social identity. In the end, a particular fashion brand that someone wears can be a determination in assessing his/her social status. In terms of quality, rich people prefer expensive restaurants that clearly provides clean and fine dishes and/or hire they own professional chefs at home. In terms of quantity, rich people can afford various types of dish and beverage to serve their important guests in special occasions. Other luxury ownership that is as well categorized as a form of social identity expression is the possession of luxury assets and properties such as homes and private vehicles.

The second expression of social identity can be seen from social image maintenance which includes strict rules of interaction and education, special occasions like wedding receptions and particular celebrations, as well as elite club memberships.

\section{REFERENCES}

Barker, C. (2000). Cultural Studies: Theory and Practice. UK: The Alden Press.

Boden, S. (2003). Consumerism, Romance, and the Wedding Experience. New York: PALGRAVE MACMILLAN.

Chua, B. H. (2000). Consuming Asians: Ideas and Issues. In B. H. Chua, Consumption in Asia: Lifestyles and Identities (pp. 1-34). United States: Routledge.

Corrigan, P. (1997). The Sociology of Consumption. Cambridge: SAGE Publications.

Davis, F. (1994). Fashion, Culture, and Identity. USA: The University of Chicago Press.

Hall, S. (1996). Who Needs Identity? In S. Hall, \& P. D. Gay, Questions of Cultural Identity (pp. 1-16). London: SAGE Publications.

Hall, S., Held, D., \& Thompson, K. (1996). Modernity: An Introduction to Modern Society. Malden: Blackwell.

Kwan, K. (2013). Crazy Rich Asians. United States: Anchor Books. 